\title{
Microsegregation and Solidification Shrinkage of Copper-Lead Base Alloys
}

\author{
B. Korojy, L. Ekbom, and H. Fredriksson \\ Department of Materials Processing, Royal Institute of Technology, Brinellvagen 23, 10044 Stockholm, Sweden \\ Correspondence should be addressed to B. Korojy, korojy@kth.se
}

Received 14 July 2009; Revised 25 October 2009; Accepted 13 December 2009

Recommended by Jainagesh Sekhar

\begin{abstract}
Microsegregation and solidification shrinkage were studied on copper-lead base alloys. A series of solidification experiments was performed, using differential thermal analysis (DTA) to evaluate the solidification process. The chemical compositions of the different phases were measured via energy dispersive X-ray spectroscopy (EDS) for the Cu-Sn- $\mathrm{Pb}$ and the Cu-Sn-Zn- $\mathrm{Pb}$ systems. The results were compared with the calculated data according to Scheil's equation. The volume change during solidification was measured for the $\mathrm{Cu}-\mathrm{Pb}$ and the $\mathrm{Cu}-\mathrm{Sn}-\mathrm{Pb}$ systems using a dilatometer that was developed to investigate the melting and solidification processes. A shrinkage model was used to explain the volume change during solidification. The theoretical model agreed reasonably well with the experimental results. The deviation appears to depend on the formation of lattice defects during the solidification process and consequently on the condensation of those defects at the end of the solidification process. The formation of lattice defects was supported by quenching experiments, giving a larger fraction of solid than expected from the equilibrium calculation.
\end{abstract}

Copyright (C) 2009 B. Korojy et al. This is an open access article distributed under the Creative Commons Attribution License, which permits unrestricted use, distribution, and reproduction in any medium, provided the original work is properly cited.

\section{Introduction}

$\mathrm{Cu}-\mathrm{Pb}, \mathrm{Cu}-\mathrm{Sn}$, and $\mathrm{Cu}-\mathrm{Sn}-\mathrm{Pb}$ systems have been investigated by several authors [1-3]. The liquidus surfaces of the $\mathrm{Cu}-\mathrm{Pb}$ and $\mathrm{Cu}-\mathrm{Sn}-\mathrm{Pb}$ equilibrium systems $[2,4]$ show a miscibility gap between copper-rich and lead-rich melts. This creates a monotectic reaction in which a lead-rich liquid is formed. Investigations show that the monotectic alloy transitions to a solid copper ( $\alpha$-phase) and lead-rich melt without any change in volume [5]. In addition, from specific volume measurements of monotectic phases, it was predicted that a melt with the monotectic composition would solidify without shrinkage in the $\mathrm{Cu}-\mathrm{Pb}$ system [6].

In this work, microsegregation and solidification processes were studied in the $\mathrm{Cu}-5 \mathrm{Sn}-5 \mathrm{~Pb}$ and the $\mathrm{Cu}-5 \mathrm{Sn}-5 \mathrm{Zn}$ $5 \mathrm{~Pb}$ alloys. The chemical compositions of the different phases were measured with an energy dispersive X-ray spectroscopy (EDS) microprobe. The results were compared with the calculated data according to Scheil's equation. Differential thermal analysis (DTA) was used to evaluate the precipitation of the primary phase and the monotectic temperature. To investigate the volume change during solidification of $\mathrm{Cu}-\mathrm{Pb}$ and $\mathrm{Cu}-\mathrm{Sn}-\mathrm{Pb}$ alloys, a specific method was developed using a dilatometer ( Netzsch DIL 402 C). A shrinkage model was used to explain the volume changes during solidification.

\section{Experimental Work}

Experimental alloys were produced in a high-frequency induction furnace under an argon atmosphere using a graphite crucible and casting into a small cylindrical copper mould. Pure Cu (99.95\%), Sn (99.9\%), Pb (99.98\%), and Zn (99.9\%) were used as starting materials to minimize trace element effects. The composition of the alloys was measured using Glow Discharge Optical Emission Spectroscopy, and the result is given in Table 1. A series of samples was prepared so that the solidification heat exchange could be determined via differential thermal analysis (DTA).

The details of the DTA have been described elsewhere [7]. In brief, the DTA equipment consists of a resistance furnace that heats and cools the sample at a controlled rate.

A sample that was $8 \mathrm{~mm}$ in diameter and $14 \mathrm{~mm}$ in height was placed in an alumina crucible that was closed with a lid using a ceramic fastener. The temperature was measured 
TABLE 1: Chemical composition of the alloys, wt.\%

\begin{tabular}{lccccc}
\hline Alloy & $\mathrm{Zn}$ & $P$ & $\mathrm{Sn}$ & $\mathrm{Pb}$ & $\mathrm{Cu}$ \\
\hline Cu-5Sn-5Pb & - & .004 & 5.2 & 4.7 & Bal. \\
Cu-5Sn-5Zn-5Pb & 4.5 & .006 & 5.2 & 4.9 & $\prime \prime$ \\
$\mathrm{Cu}-5 \mathrm{~Pb}$ & - & $<.004$ & $<0.04$ & 5 & $\prime \prime$ \\
$\mathrm{Cu}-15 \mathrm{~Pb}$ & - & $<.004$ & $<0.04$ & 15 & $\prime \prime$ \\
\hline
\end{tabular}

inside the sample using a type $S$ thermocouple with a shield of alumina. A hallow cylinder of graphite was used as a temperature reference a few millimeters around the sample. The reference temperature was also measured using a type $S$ thermocouple. Argon protective gas was passed through the furnace chamber. The samples were quenched to room temperature by letting the crucible fall into a container filled with water.

The obtained cooling curves were used to study nonequilibrium solidification processes. A constant cooling rate, $0.16 \mathrm{Ks}^{-1}$, was chosen for all of the samples. Two thermal arrest points appeared in the differential curve. The first thermal arrest corresponds to the liquidus temperature and the second is due to the monotectic reaction.

In order to evaluate the fraction of the different phases formed during solidification, some of the DTA samples were quenched at the beginning of the monotectic reaction. The microstructures of the samples were evaluated and the fraction of phases was determined using an optical microscope (Leica DMRM) equipped with an image analysis software (Q Win V3).

The copper-tin-lead and the copper-tin-zinc-lead alloys were homogenized at approximately $15 \mathrm{~K}$ above the monotectic reaction temperature for 24 hours and then quenched in water. In order to avoid oxidation during the heat treatment, the samples were placed in an evacuated quartz tube. The equilibrium composition of the primary phase was measured from the heat-treated samples.

The composition changes along the dendrites and in the quenched monotectic areas were measured using the scanning electron microscope (SEM-JSM840-JEOL) with a LINK (Isis) energy dispersive analysis system (EDS). As a reference pure cobalt was used.

A dilatometer (Netzsch DIL 402 C) was developed to investigate the volume change during solidification. Experiments were done using a cylindrical sample supporter that is made out of graphite. Figure 1 shows a schematic sketch of the sample supporter. The molten salt (calcium chloride) behaves as a lubricant to avoid sticking between the pistons and the sample. Argon protective gas was passed.

\section{Results}

3.1. Microstructure and Microsegregation. Table 2 presents the result of the thermal analyses and the volume fraction of the primary phase in the quenched samples. As can be seen, the liquidus temperature decreased in the alloy with zinc content, while the monotectic temperature increased by 10 degrees.

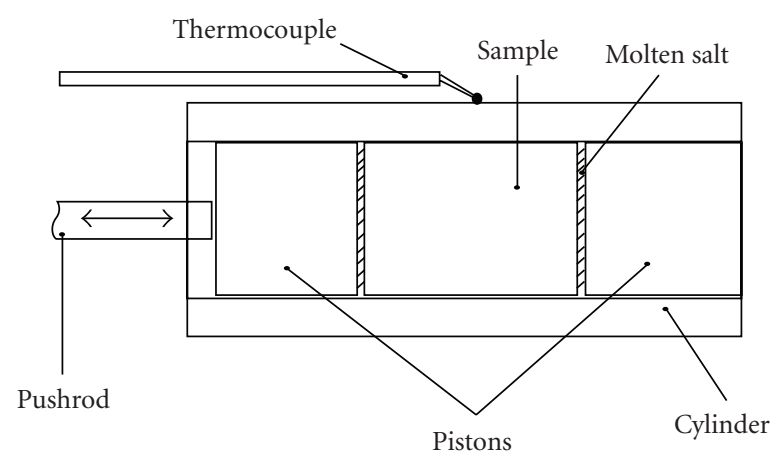

FIGURE 1: A schematic sketch of the sample supporter in the dilatometer apparatus.

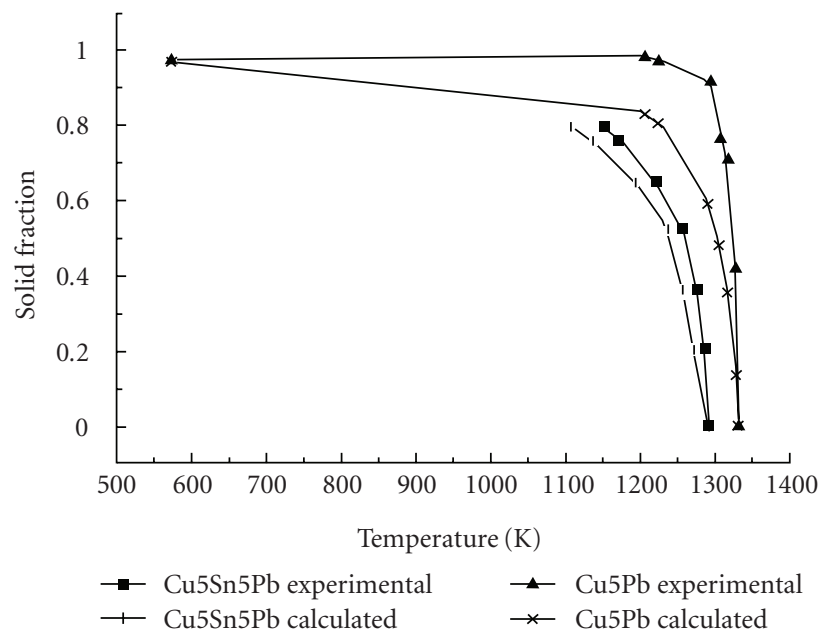

FIGURE 2: Experimental and calculated values of the solid fraction in $\mathrm{Cu}-5 \mathrm{~Pb}$ and $\mathrm{Cu}-5 \mathrm{Sn}-5 \mathrm{~Pb}$ alloys.

Figure 2 shows the experimental results and theoretical calculations concerning the lever rule for the $\mathrm{Cu}-\mathrm{Pb}$ system and Scheil's equation for the $\mathrm{Cu}-\mathrm{Sn}-\mathrm{Pb}$ system. The experimental results show a higher solid fraction than the calculated solid fraction. Furthermore, a slightly decrease in the fraction of solid present was observed after the monotectic reaction. The quenched samples were inspected to evaluate the relative fraction of pores that were precipitating during solidification.

The microstructure of the $\mathrm{Cu}-5 \mathrm{Sn}-5 \mathrm{~Pb}$ alloy solidified at a cooling rate of $0.16 \mathrm{Ks}^{-1}$ is shown in Figure 3. The early solidified part of the dendrites is etched darker. The lead phase is separated as isolated black inclusions in the late solidified part of the $\alpha$-phase. The microstructure of quenched samples consists primarily of $\alpha$ dendrites and a quenched area, as shown in Figure 4. The quenched area exhibits lead inclusions, a gray matrix phase with an internal bright phase.

A micrograph and the composition profile curves from the EDS examination of the $\mathrm{Cu}-5 \mathrm{Sn}-5 \mathrm{~Pb}$ alloy are shown in Figure 5. The initially solidified $\alpha$-phase had the lowest tin concentration (1.6 wt.\%), and it increased to $3 \mathrm{wt} . \%$ during the final part of the primary solidification. The maximum 
TABLE 2: Liquidus and monotectic temperatures for the investigated alloys as determined from the cooling curves.

\begin{tabular}{lcccc}
\hline Alloy & Cooling rate $\left(\mathrm{Ks}^{-1}\right)$ & Liquidus temp. $(\mathrm{K})$ & Monotectic temp. $(\mathrm{K})$ & Volume fraction of primary phase $(\%)$ \\
\hline $\mathrm{Cu}-5 \mathrm{~Pb}$ & 0.16 & $1330-1332$ & $1218-1221$ & $96.9 \pm 0.1$ \\
$\mathrm{Cu}-5 \mathrm{Sn}-5 \mathrm{~Pb}$ & 0.16 & $1292-1293$ & $1151-1154$ & $79.6 \pm 0.5$ \\
$\mathrm{Cu}-5 \mathrm{Sn}-5 \mathrm{Zn}-5 \mathrm{~Pb}$ & 0.16 & 1271 & $1161-1162$ & $78.4 \pm 0.6$ \\
\hline
\end{tabular}

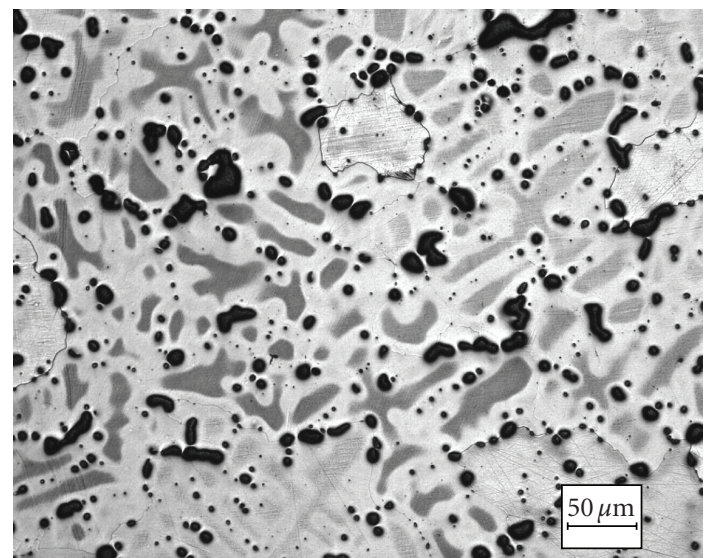

Figure 3: Microstructure of $\mathrm{Cu}-5 \mathrm{Sn}-5 \mathrm{~Pb}$ alloy solidified at a cooling rate of $0.16 \mathrm{Ks}^{-1}$.

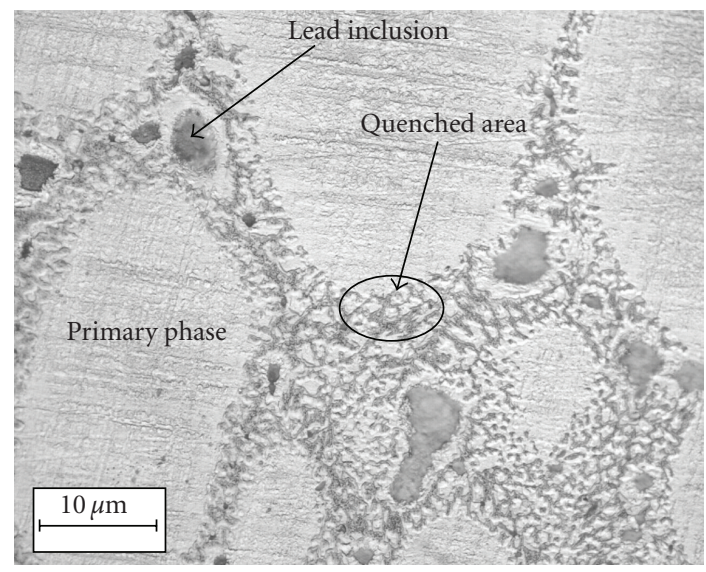

Figure 4: Microstructure of $\mathrm{Cu}-5 \mathrm{Sn}-5 \mathrm{~Pb}$ alloy quenched from monotectic temperature.

amount of tin content, $6 \mathrm{wt} . \%$, was observed in the samples that were solidified completely at a cooling rate of $0.16 \mathrm{Ks}^{-1}$. The measurements of the composition of lead inclusions showed that tin was not solved in the lead inclusions, which, according to the isothermal ternary phase diagram at $443 \mathrm{~K}$ [8], was expected. The copper content of the lead inclusions varied between 2.5 to $3.5 \mathrm{wt}$. $\%$. The copper content of the lead inclusions in the quenched samples was lower than when the samples were solidified completely at a cooling rate of $0.16 \mathrm{Ks}^{-1}$.

The microstructure evaluation of the $\mathrm{Cu}-5 \mathrm{Sn}-5 \mathrm{Zn}-5 \mathrm{~Pb}$ alloy, shown in Figure 6, demonstrates the same morphology as that of the $\mathrm{Cu}-5 \mathrm{Sn}-5 \mathrm{~Pb}$ alloy. The microprobe analysis showed that tin segregated into the liquid, but the concentration of zinc in the $\alpha$-phase is higher than the liquid.

Table 3 gives the result of the EDS measurements on the homogenized samples. It can be seen that when zinc was added to the $\mathrm{Cu}-\mathrm{Sn}-\mathrm{Pb}$ system, the tin content in the primary phase decreased. In addition, the experimental results show that the so-called the partition coefficient of zinc is larger than one.

\subsection{Calculation of the Microsegregation}

3.2.1. $\mathrm{Cu}$ - $\mathrm{Pb}$ System. According to the $\mathrm{Cu}-\mathrm{Pb}$ phase diagram [9], the alloys with a lead content of less than $37.4 \mathrm{wt} . \%$ start to solidify as pure copper. A monotectic reaction starts at $1228 \mathrm{~K}$, during which a lead-rich liquid with a $\mathrm{Cu}$-content of $86 \mathrm{wt} . \%$ is formed. The solidification can be described using the lever rule

$$
C_{\mathrm{Pb}}^{L}=\frac{C_{\mathrm{Pb}}^{o L}}{1-f_{S}\left(1-K_{\mathrm{Pb}}\right)},
$$

where $f_{S}$ is the solid fraction. $C_{\mathrm{Pb}}^{L}$ is the liquid composition and $C_{\mathrm{Pb}}^{o L}$ is the initial composition of liquid. $K_{\mathrm{Pb}}$ represents the partition coefficient of lead, which is equal to zero. Figure 2 shows the calculated and experimental values of the solid fraction in the $\mathrm{Cu}-5 \mathrm{~Pb}$ alloy.

3.2.2. $\mathrm{Cu}-\mathrm{Sn}$ - $\mathrm{Pb}$ System. In the $\mathrm{Cu}-\mathrm{Sn}-\mathrm{Pb}$ system, the volume fraction of the primary $\alpha$-phase and the lead content of the monotectic melt can be calculated according to Fredriksson [10]. During the primary precipitation of the $\alpha$-phase, the concentrations of the alloying elements $C_{\mathrm{Sn}}^{L}$ and $C_{\mathrm{Pb}}^{L}$ in the melt are described by the following equations:

$$
\begin{aligned}
& C_{\mathrm{Sn}}^{L}=C_{\mathrm{Sn}}^{o L}\left(1-f_{\alpha}\right)^{-\left(1-K_{\mathrm{Sn}}^{\alpha L}\right)} \\
& C_{\mathrm{Pb}}^{L}=C_{\mathrm{Pb}}^{o L}\left(1-f_{\alpha}\right)^{-\left(1-K_{\mathrm{Pb}}^{\alpha L}\right)},
\end{aligned}
$$

where the initial concentrations of tin and lead are $C_{S_{n}}^{o L}=$ 5.24 wt. $\%$ and $C_{\mathrm{Pb}}^{o L}=4.76$ wt. $\%$, respectively. The exponential term of $-\left(1-K_{\mathrm{Sn}}^{\alpha \mathrm{L}}\right)$ and $-\left(1-K_{\mathrm{Pb}}^{\alpha \mathrm{L}}\right)$ describes the extensive change in the melt composition, in accordance with Scheil's equation. The partition coefficients are $K_{\mathrm{Sn}}^{\alpha L}=0.368$ and $K_{\mathrm{Pb}}^{\alpha L}=0$ driven from the binary phase diagrams [9].

Table 4 presents the liquid composition of the $\mathrm{Cu}-5 \mathrm{Sn}$ $5 \mathrm{~Pb}$ alloy, which were calculated using the experimental solid fraction. The calculated liquid composition at $1173 \mathrm{~K}$ is in good agreement with the EDS measurements on the homogenized sample (Table 3). The line (PQ), Figure 7 [4], shows the composition of the $\alpha$-phase during the solidification of the $\mathrm{Cu}-5 \mathrm{Sn}-5 \mathrm{~Pb}$ alloy according to the calculated values. 


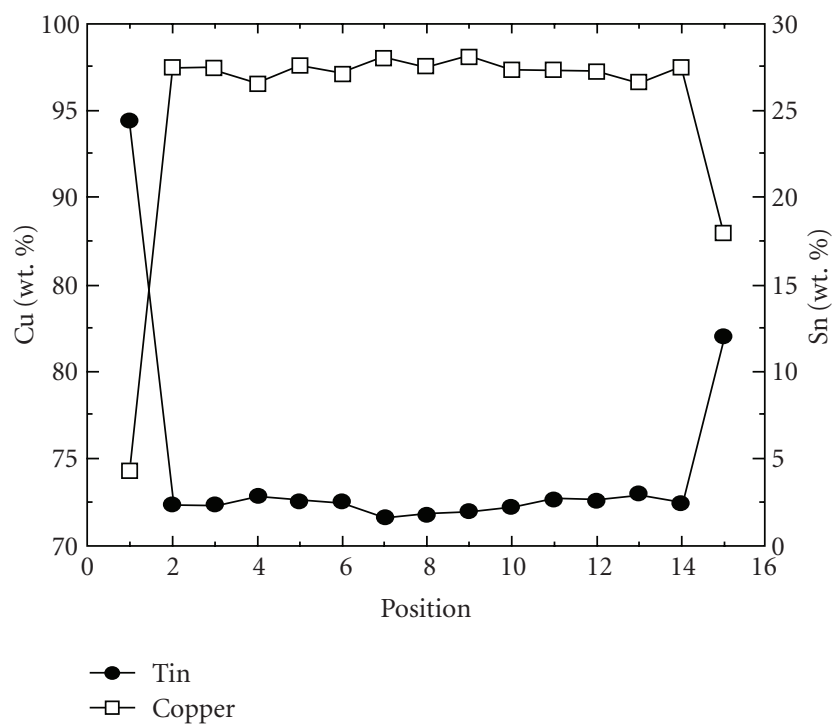

(a)

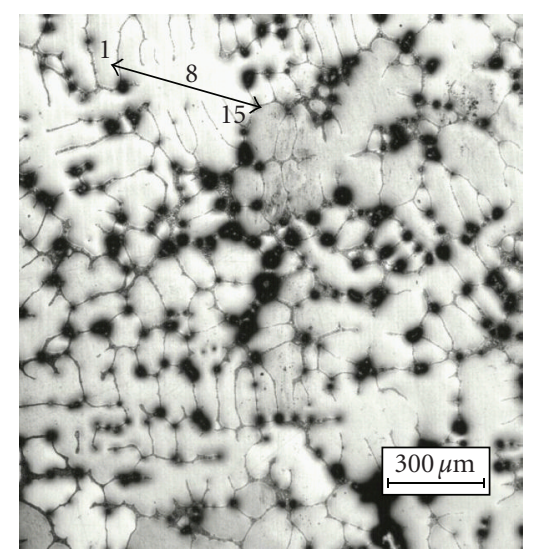

(b)

Figure 5: (a) Composition profile through a dendrite cross section in $\mathrm{Cu}-5 \mathrm{Sn}-5 \mathrm{~Pb}$ alloy that was quenched from the monotectic temperature. (b) Micrograph of a dendrite cross section in $\mathrm{Cu}-5 \mathrm{Sn}-5 \mathrm{~Pb}$ alloy that was quenched from the monotectic temperature.

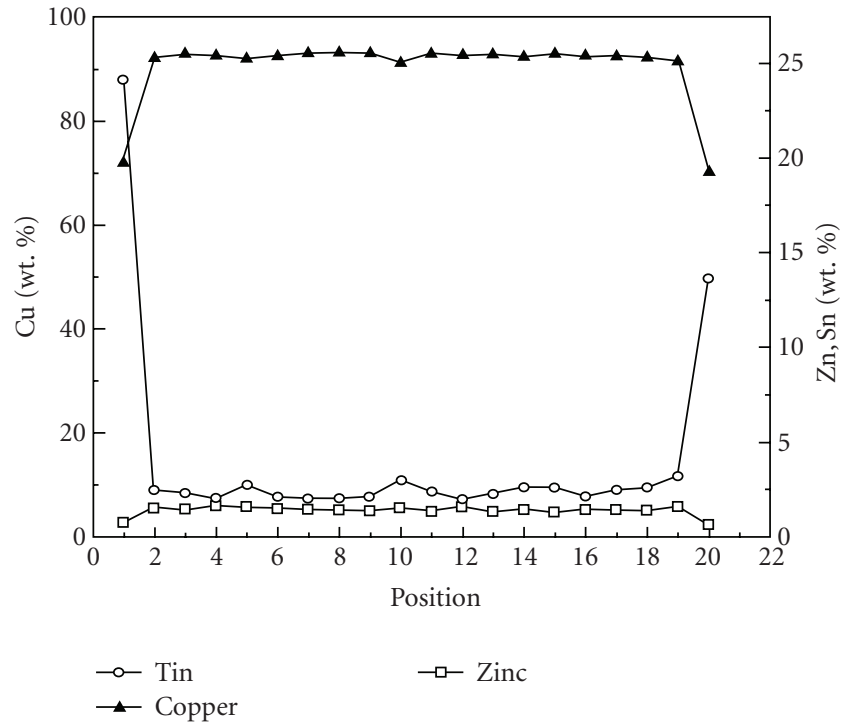

(a)

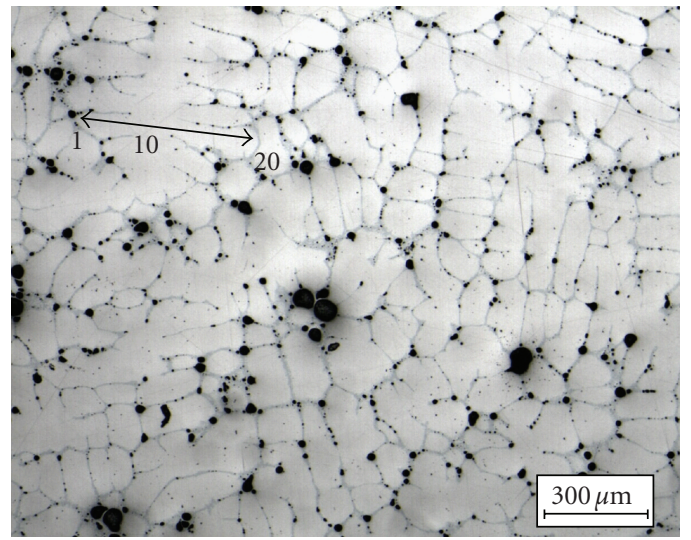

(b)

Figure 6: (a) Composition profile through a dendrite cross section in $\mathrm{Cu}-5 \mathrm{Sn}-5 \mathrm{Zn}-5 \mathrm{~Pb}$ alloy that was quenched after the primary solidification. (b) Micrograph of a dendrite cross section in $\mathrm{Cu}-5 \mathrm{Sn}-5 \mathrm{Zn}-5 \mathrm{~Pb}$ alloy that was quenched after the primary solidification.

TABLE 3: Chemical composition of different phases in heat treated samples (95\% interval confidence)

\begin{tabular}{|c|c|c|c|c|c|}
\hline \multicolumn{2}{|c|}{ Alloy } & Sn (wt.\%) & Zn (wt.\%) & $\mathrm{Pb}$ (wt.\%) & $\mathrm{Cu}$ (wt.\%) \\
\hline \multirow{2}{*}{$\mathrm{Cu}-5 \mathrm{Sn}-5 \mathrm{~Pb}$} & Primary phase & $3.25 \pm 0.08$ & - & - & Bal. \\
\hline & Quenched area & $12.39 \pm 0.56$ & - & $18.63 \pm 2.38$ & Bal. \\
\hline \multirow{2}{*}{$\mathrm{Cu}-5 \mathrm{Sn}-5 \mathrm{Zn}-5 \mathrm{~Pb}$} & Primary phase & $2.77 \pm 0.11$ & $4.35 \pm 0.14$ & - & Bal. \\
\hline & Quenched area & $11.98 \pm 0.59$ & $2.30 \pm 0.12$ & $18.87 \pm 2.51$ & Bal. \\
\hline
\end{tabular}




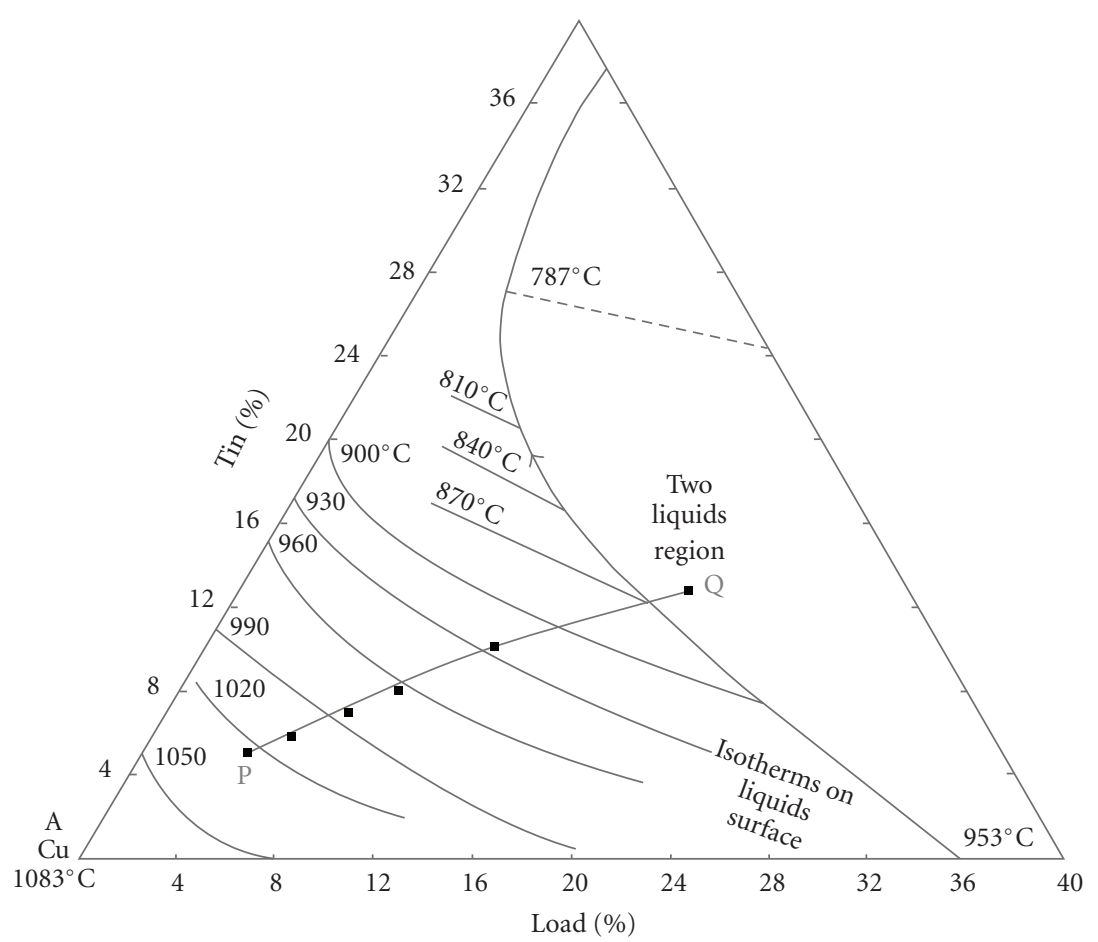

FIGURE 7: Liquidus surface of the copper-tin-lead ternary system [4].

TABLE 4: Calculated liquid composition during the solidification of the $\mathrm{Cu}-5 \mathrm{Sn}-5 \mathrm{~Pb}$ alloy.

\begin{tabular}{lccc}
\hline Temperature (K) & Solid Fraction & $C_{\mathrm{Sn}}^{L}($ wt.\%) & $C_{\mathrm{Pb}}^{L}(\mathrm{wt} . \%)$ \\
\hline 1293 & 0 & 5.24 & 4.76 \\
1288 & 0.205 & 6.06 & 5.99 \\
1278 & 0.364 & 6.98 & 7.48 \\
1258 & 0.525 & 8.39 & 10.02 \\
1223 & 0.648 & 10.14 & 13.25 \\
1173 & 0.758 & 12.85 & 19.67 \\
\hline
\end{tabular}

3.2.3. $\mathrm{Cu}-\mathrm{Zn}-\mathrm{Sn}-\mathrm{Pb}$ System. The same calculation can be done for the $\mathrm{Cu}-\mathrm{Sn}-\mathrm{Zn}-\mathrm{Pb}$ system using (2), (3) and (3):

$$
C_{Z n}^{L}=C_{Z n}^{o L}\left(1-f_{\alpha}\right)^{-\left(1-K_{Z n}^{\alpha L}\right)}
$$

The initial concentrations of the alloys $C_{S n}^{L}=5.27$ wt.\%, $C_{Z n}^{L}=4.54 \mathrm{wt} . \%$, and $C_{\mathrm{Pb}}^{L}=4.90 \mathrm{wt} . \%$ are given. The partition coefficients are $K_{S n}^{\alpha L}=0.231, K_{Z n}^{\alpha L}=1.89$, and $K_{\mathrm{Pb}}^{\alpha L}=0$. Because of the inverse segregation of zinc, the partition coefficients of the alloying elements were evaluated from the experimental values.

The composition of the liquid was calculated using the solid fraction of the $\mathrm{Cu}-5 \mathrm{Sn}-5 \mathrm{Zn}-5 \mathrm{~Pb}$ alloy at the monotectic temperature:

$$
\begin{gathered}
C_{\mathrm{Pb}}^{L}=22.68 \text { wt. \%, } \quad C_{\mathrm{Sn}}^{L}=13.88 \text { wt. \%, } \\
C_{Z n}^{L}=1.15 \text { wt. } \% .
\end{gathered}
$$

These results indicate that the approximation that is applied to the $\mathrm{Cu}-\mathrm{Sn}-\mathrm{Pb}$ system cannot be valid for the $\mathrm{Cu}-$ $\mathrm{Sn}-\mathrm{Zn}-\mathrm{Pb}$ system. In fact, the calculation is based on the microsegregation behaviour of binary system in which the partition coefficient of zinc is less than one [9], but the microsegregation of zinc changed to the contrary in the $\mathrm{Cu}-$ $\mathrm{Sn}-\mathrm{Zn}-\mathrm{Pb}$ system.

3.3. Volume Changes and Shrinkage. The volume change during solidification and melting was evaluated between the liquidus and the monotectic temperatures of the $\mathrm{Cu}$ $\mathrm{Pb}$ alloy. The results are given in Table 5. In each run, the volume change during melting of the $\mathrm{Cu}-\mathrm{Pb}$ alloy was larger than the volume change during solidification of the $\mathrm{Cu}$ $\mathrm{Pb}$ alloy. In addition, increasing the lead content decreased the volume change during the solidification and melting processes. The monotectic reaction took place without any measurable volume change in the $\mathrm{Cu}-5 \mathrm{~Pb}$ alloy, as shown in Figure 8. Moreover, the contraction of the alloy was linear below the monotectic reaction, as is the case for a solid phase. The expansion coefficient measurement showed that increasing the cooling rate decreased the liquid expansion coefficient, whereas the expansion coefficient of the sample below the monotectic temperature increased.

The experimental and calculated solidification shrinkage of the $\mathrm{Cu}-5 \mathrm{Sn}-5 \mathrm{~Pb}$ alloy is shown in Figure 9. The experimental curve demonstrates an expansion below $1203 \mathrm{~K}$. However, the major part of the expansion occurred as the same time as the monotectic reaction, during which a leadrich liquid is formed. Table 6 presents the volume change of the $\mathrm{Cu}-5 \mathrm{Sn}-5 \mathrm{~Pb}$ alloy during melting and solidification at heating and cooling rates of $0.016 \mathrm{Ks}^{-1}$. 
TABLE 5: Volume change and thermal expansion coefficient of the $\mathrm{Cu}-\mathrm{Pb}$ alloys.

\begin{tabular}{|c|c|c|c|c|c|c|}
\hline \multirow[t]{2}{*}{ Alloy } & \multirow[t]{2}{*}{$\begin{array}{l}\text { Cooling \& heating } \\
\quad \text { rate }\left(\mathrm{Ks}^{-1}\right)\end{array}$} & \multirow{2}{*}{$\begin{array}{c}\alpha_{s} \text { below monotectic } \\
\text { temp. }\left(\mathrm{K}^{-1}\right) \times 10^{6} \\
\text { Cooling }\end{array}$} & \multicolumn{2}{|c|}{$\begin{array}{l}\text { Volume change between monotectic } \\
\text { and liquidus temperature (\%) }\end{array}$} & \multicolumn{2}{|c|}{$\begin{array}{c}\alpha_{l} \text { above liquidus } \\
\quad\left(\mathrm{K}^{-1}\right) \times 10^{6}\end{array}$} \\
\hline & & & Melting & Solidifying & Heating & Cooling \\
\hline \multirow{4}{*}{$\mathrm{Cu}-5 \mathrm{~Pb}$} & 0.016 & $16.23 \pm 0.60$ & $3.89 \pm 0.04$ & $3.77 \pm 0.11$ & $23.05 \pm 0.81$ & $23.40 \pm 0.94$ \\
\hline & 0.032 & $16.73 \pm 0.92$ & $3.71 \pm 0.29$ & $3.57 \pm 0.32$ & $22.70 \pm 3.54$ & $22.67 \pm 3.34$ \\
\hline & 0.083 & $20.26 \pm 1.70$ & $3.39 \pm 0.71$ & $3.64 \pm 1.08$ & $22.95 \pm 0.41$ & $20.21 \pm 0.024$ \\
\hline & 0.167 & $21.26 \pm 0.35$ & $3.27 \pm 0.33$ & $3.24 \pm 0.06$ & $21.46 \pm 0.69$ & $19.13 \pm 1.05$ \\
\hline $\mathrm{Cu}-15 \mathrm{~Pb}$ & 0.016 & - & $3.26 \pm 0.01$ & $3.00 \pm 0.03$ & $23.03 \pm 0.57$ & $19.11 \pm 1.77$ \\
\hline
\end{tabular}

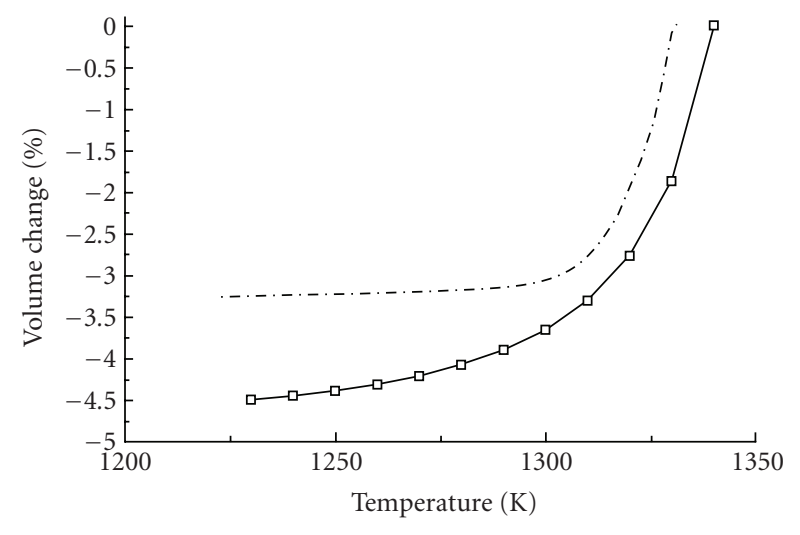

$\cdot-\cdot$ Experimental
$\rightarrow-$ Model

Figure 8: Experimental and modeling results of the solidification shrinkage in the $\mathrm{Cu}-5 \mathrm{~Pb}$ alloy.

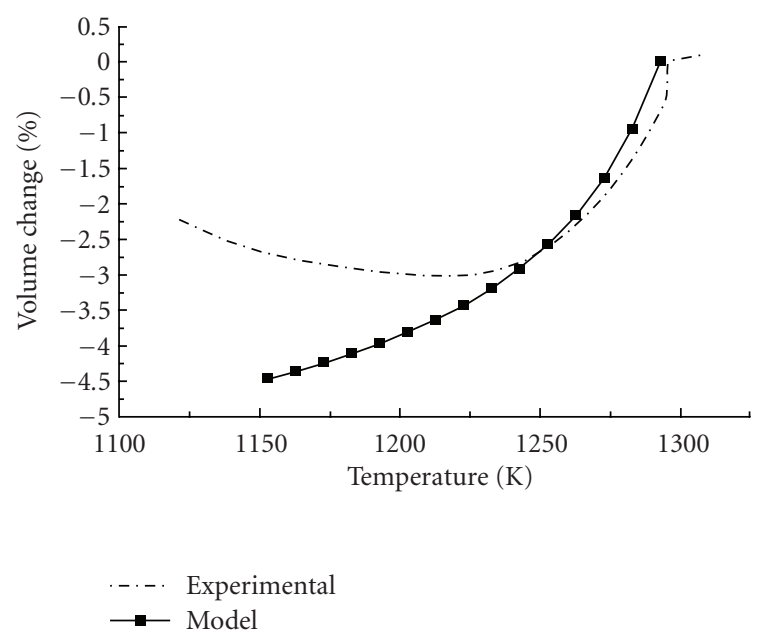

FIGURE 9: Experimental and modeling results of the solidification shrinkage in $\mathrm{Cu}-5 \mathrm{Sn}-5 \mathrm{~Pb}$ alloy.

3.4. Shrinkage Calculation. The solidification shrinkage can be described as the sum of four parts. The first part is the shrinkage due to change from the liquid to the solid state, which is determined by the $\beta$ value. The second and third parts are, respectively, the volume change in the solid and the liquid phases during cooling within the temperature interval.
TABle 6: Volume change of the $\mathrm{Cu}-5 \mathrm{Sn}-5 \mathrm{~Pb}$ alloy during melting and solidification in term of percentage at a cooling rate of $0.016 \mathrm{Ks}^{-1}$.

\begin{tabular}{cccc}
\hline \multicolumn{2}{c}{ Melting } & \multicolumn{2}{c}{ Solidifying } \\
Before & After & After & Before \\
Monotectic & Monotectic & Monotectic & Monotectic \\
\hline$-1.28 \pm 0.09$ & $3.57 \pm 0.13$ & $1.04 \pm 0.10$ & $-3.25 \pm 0.24$ \\
\hline
\end{tabular}

The last part is the volume change due to the change in the liquid composition. The differential (5) and (6) express the temperature derivative of the total volume:

$$
\frac{d V_{\text {Total }}}{d T}=\frac{d V_{S}}{d T}+\frac{d V_{L}}{d T}+\frac{d V^{L \rightarrow S}}{d T}+\frac{d V^{\text {Comp }}}{d T},
$$

$$
\begin{aligned}
\frac{d V_{\text {Total }}}{d T}= & 3 \alpha_{S} V_{0}^{S}\left(T_{0}-T\right) \frac{d f_{S}}{d T}+3 \alpha_{L} V_{0}^{L}\left(T_{0}-T\right) \frac{d f_{L}}{d T} \\
& +\beta V_{0}^{L} \frac{d f_{L}}{d T}+\beta^{\operatorname{Comp}}\left(C_{0}-C_{L}\right) V_{0}^{L} \frac{d f_{L}}{d T},
\end{aligned}
$$

where $V$ represents the volume and $\alpha_{S}$ and $\alpha_{L}$ are the thermal expansion coefficients of solid and liquid, respectively. The solid and liquid fractions are $f_{S}$ and $f_{L}$, respectively. The volumetric expansion coefficient is represented by $\beta . C_{0}$ is the initial composition and $C_{L}$ is the liquidus composition, which can be extracted from the $\mathrm{Cu}-\mathrm{Pb}$ phase diagram [9]. $T_{0}$ is the liquidus temperature, and $\beta^{\text {Comp }}$ is defined as a volumetric expansion coefficient that is due to the composition change. $\beta^{\text {Comp }}$ is calculated using (7):

$$
\beta^{\mathrm{Comp}}=\frac{1}{V_{0}^{L}} \frac{\partial V_{L}}{\partial C} .
$$

The literature data [6] give an analytical relation between the specific volume of the melt and its lead content, which is presented in Table 7 and used to calculate $\beta_{\mathrm{Cu}-\mathrm{Pb}}^{\mathrm{Comp}}$. The result is given by (8):

$$
\beta_{\mathrm{Cu}-\mathrm{Pb}}^{\mathrm{Comp}}=\frac{1}{V_{0}^{L}}\left(4.34 \times 10^{-6} C_{L}^{\mathrm{Pb}}-4.605 \times 10^{-4}\right) .
$$

The $\beta$ value is defined using (9):

$$
\beta=\frac{V_{L}-V_{S}}{V_{L}}
$$


where $V_{L}$ and $V_{S}$ are defined by (10) and (11) separately:

$$
\begin{gathered}
V_{L}=V_{0}^{L}\left[1-3 \alpha_{L}^{T}\left(T-T_{0}\right)+\beta_{\mathrm{Cu}-\mathrm{Pb}}^{\mathrm{Comp}}\left(C_{L}-C_{0}\right)\right], \\
V_{S}=V_{0}^{S}\left[1-3 \alpha_{S}^{T}\left(T-T_{0}\right)\right] .
\end{gathered}
$$

According to (8), (10), (11), literature data [11], and the $\mathrm{Cu}-\mathrm{Pb}$ phase diagram [9], the $\beta$ value can be calculated as a function of temperature, as given by (12):

$$
\beta^{\mathrm{Cu}-\mathrm{Pb}}=8.8 \times 10^{-4} \mathrm{~T}-0.8902 .
$$

The total volume change from liquidus to the monotectic temperature can be calculated by integrating of (6). The total volume change of the $\mathrm{Cu}-5 \mathrm{~Pb}$ alloy is plotted in Figure 8 as a function of the temperature by using data from other studies (as presented in Table 7 for $\mathrm{Cu}-\mathrm{Pb}, \mathrm{Cu}-$ $\mathrm{Sn}-\mathrm{Pb}$, and $\mathrm{Cu}-\mathrm{Sn}-\mathrm{Zn}-\mathrm{Pb}$ systems). The lever rule was used to calculate $f_{S}$ and $f_{L}$. As can be seen, the model predicts a shrinkage behavior that is similar to that demonstrated by the experimental results. The difference between the experimental and calculated values is partly due to the pore formation (e.g., 0.35 vol.\% at $1295 \mathrm{~K}$ ) and the difference in the actual and experimental liquidus temperature.

At the monotectic temperature, the following reaction takes place:

$$
L \longrightarrow C u_{S}+C u_{L}(\mathrm{~Pb}) .
$$

The following relation gives the volume change of the monotectic reaction:

$$
\begin{aligned}
d V & =f_{L}^{\mathrm{Mono}} \\
& \times\left(V_{L}^{\mathrm{Mono}}-f_{S}^{\mathrm{Cu}-\mathrm{Mono}} V_{S}^{\mathrm{Cu}-\mathrm{Mono}}-f_{L-\text { Mono }}^{\mathrm{Cu}-\mathrm{Pb}} V_{L-\mathrm{Mono}}^{\mathrm{Cu}-\mathrm{Pb}}\right),
\end{aligned}
$$

where $f_{L}^{\text {Mono }}$ is the fraction of liquid that is contributed in the monotectic reaction. $f_{S}^{\mathrm{Cu}-\mathrm{Mono}}$ and $f_{L-\text { Mono }}^{\mathrm{Cu}-\mathrm{Pb}}$ are the fraction of the monotectic products that are evaluated from the phase diagram. $V_{L}^{\text {Mono }}$ is the specific volume of the melt before the monotectic reaction. $V_{S}^{\mathrm{Cu}-\mathrm{Mono}}$ and $V_{L-M o n o}^{\mathrm{Cu}-\mathrm{Pb}}$ are the specific volumes of the phases that are produced during the monotectic reaction; for example, the volume change is zero for the monotectic composition in the $\mathrm{Cu}-\mathrm{Pb}$ system.

Equation (15) is derived in order to evaluate the total thermal expansion coefficient of the $\mathrm{Cu}-5 \mathrm{~Pb}$ alloy below the monotectic temperature:

$$
\alpha_{\text {Total }}^{\mathrm{Cuspb}}=f_{S}^{\text {primary }} \alpha_{S}^{\mathrm{Cu}}+f^{\mathrm{Mono}} \bar{\alpha}_{\text {Mono }} .
$$

\begin{tabular}{|c|c|}
\hline \multicolumn{2}{|l|}{$\mathrm{Cu}-\mathrm{Pb}$ Alloy } \\
\hline$V_{L}^{\text {Mono }}=0.1092\left(\mathrm{~cm}^{3} \mathrm{~g}^{-1}\right)$ & {$[6]$} \\
\hline$V_{L-\text { Mono }}^{\mathrm{Cu}-\mathrm{Pb}}=0.099\left(\mathrm{~cm}^{3} \mathrm{~g}^{-1}\right)$ & [6] \\
\hline$V_{S}^{\mathrm{Cu}-\mathrm{Mono}}=0.1183\left(\mathrm{~cm}^{3} \mathrm{~g}^{-1}\right)$ & {$[11]$} \\
\hline$V_{0}^{L}=0.123\left(\mathrm{~cm}^{3} \mathrm{~g}^{-1}\right)$ & [6] \\
\hline$V_{0}^{\mathrm{Cu}}=V_{0}^{S}=0.119\left(\mathrm{~cm}^{3} \mathrm{~g}^{-1}\right)$ & {$[11]$} \\
\hline$\alpha_{L}^{\mathrm{Cu}-\mathrm{Pb}}=36.14 \times 10^{-6}\left(\mathrm{~K}^{-1}\right)$ & {$[6]$} \\
\hline$\alpha_{S}^{\mathrm{Cu}-\mathrm{Pb}}=\alpha_{S}^{\mathrm{Cu}}=20.3 \times 10^{-6}\left(\mathrm{~K}^{-1}\right)$ & [12] \\
\hline$\beta^{\text {Mono }}=0.187$ & (Expansion) [6] \\
\hline$C_{L}=-0.287 T+312.4($ wt. \%) & [9] \\
\hline$C_{L}^{\text {Mono }}=-0.133 T+213(\mathrm{wt} . \%)$ & [9] \\
\hline \multicolumn{2}{|l|}{$C_{o}=5($ wt. $\%)$} \\
\hline$T_{o}=1340(\mathrm{~K})$ & Calculated \\
\hline$T_{M}=1357.87(\mathrm{~K})$ & [9] \\
\hline $\mathrm{T}_{\text {Mono }}=1228(\mathrm{~K})$ & [9] \\
\hline \multicolumn{2}{|l|}{$V_{\mathrm{Cu}-\mathrm{Pb}}^{L}=2.17 \times 10^{-6} C_{\mathrm{Pb}}^{2}-4.605$} \\
\hline$\times 10^{-4} C_{\mathrm{Pb}}+0.1253\left(\mathrm{~cm}^{3} \mathrm{~g}^{-1}\right)$ & [6] \\
\hline \multicolumn{2}{|l|}{$\mathrm{Cu}-\mathrm{Sn}-\mathrm{Pb}$ Alloy } \\
\hline$V_{0}^{L}=0.124\left(\mathrm{~cm}^{3} \mathrm{~g}^{-1}\right)$ & {$[6]$} \\
\hline$V_{0}^{S}=0.118\left(\mathrm{~cm}^{3} \mathrm{~g}^{-1}\right)$ & [11] \\
\hline$K_{\mathrm{Sn}}=\frac{C_{S}}{C_{J}}=0.368$ & [9] \\
\hline$\alpha_{L}^{\mathrm{Cu}-\mathrm{Sn}-\mathrm{Pb}}=26.6 \times 10^{-6}\left(\mathrm{~K}^{-1}\right)$ & Experimental \\
\hline 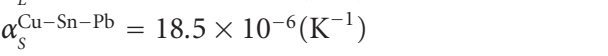 & {$[12]$} \\
\hline \multicolumn{2}{|l|}{$C_{o}^{S \mathrm{n}}=5.2(\mathrm{wt} . \%)$} \\
\hline \multicolumn{2}{|l|}{$C_{o}^{\mathrm{Pb}}=4.7(\mathrm{wt} . \%)$} \\
\hline$T_{M}=1357.87(\mathrm{~K})$ & [9] \\
\hline$T_{o}=1293(\mathrm{~K})$ & Calculated \\
\hline \multicolumn{2}{|l|}{$V_{\mathrm{Cu}-\mathrm{Pb}-\mathrm{Sn}}^{L}=2.17 \times 10^{-6} C_{\mathrm{Pb}}^{2}-4.605$} \\
\hline$\times 10^{-4} C_{\mathrm{pb}}+1.1810 \times 10^{-4} C_{\mathrm{Sn}}+0.1253\left(\mathrm{~cm}^{3} \mathrm{~g}^{-1}\right)$ & [6] \\
\hline$\beta^{\mathrm{Cu}-\mathrm{Sn}-\mathrm{Pb}}=2.45 \times 10^{-4} \mathrm{~T}-0.2042$ & Calculated \\
\hline \multicolumn{2}{|l|}{ Cu-Sn-Zn-Pb Alloy } \\
\hline$V_{0}^{L}=0.126\left(\mathrm{~cm}^{3} \mathrm{~g}^{-1}\right)$ & [6] \\
\hline$V_{0}^{S} \simeq 0.1187\left(\mathrm{~cm}^{3} \mathrm{~g}^{-1}\right)$ & Calculated \\
\hline$K_{\mathrm{Sn}}=\frac{C_{S}}{C_{I}}=0.368$ & {$[9]$} \\
\hline$\alpha_{L}^{\mathrm{Cu}-\mathrm{Sn}-\mathrm{Pb}}=26.6 \times 10^{-6}\left(\mathrm{~K}^{-1}\right)$ & Experimental \\
\hline$\alpha_{S}^{\mathrm{Cu}-\mathrm{Sn}-\mathrm{Pb}} \simeq 18.5 \times 10^{-6}\left(\mathrm{~K}^{-1}\right)$ & {$[12]$} \\
\hline \multicolumn{2}{|l|}{$C_{o}=5(\mathrm{wt} . \%)$} \\
\hline$T_{M}=1357.87(\mathrm{~K})$ & [9] \\
\hline$T_{o}=1273(\mathrm{~K})$ & Calculated \\
\hline \multicolumn{2}{|l|}{$V_{\mathrm{Cu}-\mathrm{Pb}-\mathrm{Sn}-Z n}^{L}=2.17 \times 10^{-6} C_{\mathrm{Pb}}^{2}-4.605$} \\
\hline \multicolumn{2}{|l|}{$\times 10^{-4} C_{\mathrm{Pb}}+1.1810 \times 10^{-4} C_{S \mathrm{n}}+7.6$} \\
\hline$\times 10^{-4} C_{Z n}+0.1253\left(\mathrm{~cm}^{3} \mathrm{~g}^{-1}\right)$ & [6] \\
\hline$\beta^{\mathrm{Cu}-\mathrm{Sn}-Z n-\mathrm{Pb}}=4.8 \times 10^{-4} T-0.4072$ & Calculated \\
\hline
\end{tabular}

The thermal expansion coefficient of the monotectic phases, $\bar{\alpha}_{\text {Mono, }}$ is expressed by (16):

$$
\begin{aligned}
3 \bar{\alpha}_{\text {Mono }} V_{\text {Mono }}= & 3 \alpha_{S}^{\mathrm{Cu}} V_{S}^{\mathrm{Cu}-\mathrm{Mono}} f_{s}^{\mathrm{Cu}-\mathrm{Mono}} \\
& +3 \alpha_{L} V_{L-\text { Mono }}^{\mathrm{Cu}-\mathrm{Pb}} f_{L-\text { Mono }}^{\mathrm{Cu}-\mathrm{Pb}} \\
& +\beta^{\mathrm{Mono}} V_{L-\text { Mono }}^{\mathrm{Cu}-\mathrm{Pb}} \frac{d f_{L}}{d T} \\
& +\beta_{\mathrm{Cu}-\mathrm{Pb}}^{\mathrm{Comp}}\left(C_{0}-C_{L}^{\mathrm{Mono}}\right) V_{L-\text { Mono }}^{\mathrm{Cu}-\mathrm{Pb}} \frac{d f_{L}}{d T},
\end{aligned}
$$

TABLE 7

where

$$
\begin{aligned}
V_{\text {Mono }}= & f_{S}^{\mathrm{Cu}-\mathrm{Mono} o} V_{0}^{\mathrm{Cu}}\left(1-3 \alpha_{S}^{\mathrm{Cu}}\left(T_{M}-T_{\text {Mono }}\right)\right) \\
& +f_{L-\text { Mono }}^{\mathrm{Cu}-\mathrm{Pb}} V_{L-\text { Mono }}^{\mathrm{Cu}-\mathrm{Pb}} \\
V_{S}^{\mathrm{Cu}-\mathrm{Mono}}= & V_{0}^{\mathrm{Cu}}\left(1-3 \alpha_{S}^{\mathrm{Cu}}\left(T_{M}-T_{\mathrm{Mono}}\right)\right) .
\end{aligned}
$$


The last term of (16) is the volume change of the liquid after the monotectic reaction, which is calculated from literature data [6]. The total thermal expansion coefficient of the $\mathrm{Cu}$ $5 \mathrm{~Pb}$ alloy $\alpha_{\mathrm{Total}}^{\mathrm{Cu} P \mathrm{~Pb}}$ is $15.9 \times 10^{-6} \mathrm{~K}^{-1}$. The $\alpha_{\mathrm{Total}}^{\mathrm{Cu} P \mathrm{~Pb}}$ value is lower than the experimental values in Table 5 , which are evaluated from nonequilibrium solidification processes, and the difference becomes larger when the cooling rate increases.

The shrinkage model is applied to the ternary and quaternary alloys. Scheil's equation was used to calculate the solid fraction and the composition of the liquid. The compositional volume changes were evaluated from literature data [6]. It appears that when tin and zinc are added to a copperlead alloy, the specific volume varies with composition in parallel with the copper-lead alloy. Thus, $\beta^{\text {Comp }}$ of the alloys can be calculated from $\beta_{\mathrm{Cu}-\mathrm{Pb}}^{\mathrm{Comp}}$ by adding the effect of tin and zinc content on the specific volume of the $\mathrm{Cu}-\mathrm{Pb}$ alloy. Therefore, in this case, the volume change of the liquid due to a change of the tin and zinc content has to be considered. Thus (6) can now be written as

$$
\begin{aligned}
\frac{d V_{\text {Total }}}{d T}= & 3 \alpha_{S} V_{0}^{S}\left(T_{0}-T\right) \frac{d f_{S}}{d T}+3 \alpha_{L} V_{0}^{L}\left(T_{0}-T\right) \frac{d f_{L}}{d T} \\
& +\beta V_{0}^{L} \frac{d f_{L}}{d T}+\beta_{\mathrm{Pb}}^{\mathrm{Comp}}\left(C_{0}^{\mathrm{Pb}}-C_{L}^{\mathrm{Pb}}\right) V_{0}^{L} \frac{d f_{L}}{d T} \\
& +\beta_{\mathrm{Sn}}^{\mathrm{Comp}}\left(C_{0}^{\mathrm{Sn}}-C_{L}^{\mathrm{Sn}}\right) V_{0}^{L} \frac{d f_{L}}{d T} \\
& +\beta_{Z n}^{\mathrm{Comp}}\left(C_{0}^{Z n}-C_{L}^{Z n}\right) V_{0}^{L} \frac{d f_{L}}{d T},
\end{aligned}
$$

where

$$
\begin{aligned}
& \beta_{\mathrm{Pb}}^{\text {Comp }}=\frac{1}{V_{0}^{L}} \frac{\partial V_{L}}{\partial C_{\mathrm{Pb}}}, \\
& \beta_{\mathrm{Sn}}^{\text {Comp }}=\frac{1}{V_{0}^{L}} \frac{\partial V_{L}}{\partial C_{\mathrm{Sn}}}, \\
& \beta_{Z n}^{\text {Comp }}=\frac{1}{V_{0}^{L}} \frac{\partial V_{L}}{\partial C_{Z n}} .
\end{aligned}
$$

Figure 9 shows the experimental and theoretical results for the volume change of the $\mathrm{Cu}-5 \mathrm{~Pb}-5 \mathrm{Sn}$ alloy as a function of temperature. Equation (9) calculates the $\beta$ value of the $\mathrm{Cu}-$ $5 \mathrm{~Pb}-5 \mathrm{Sn}$ alloy when $V_{L}$ is defined by $(21)$ :

$$
\begin{gathered}
V_{L}=V_{0}^{L}\left[1-3 \alpha_{L}^{T}\left(T-T_{0}\right)+\beta_{\mathrm{Pb}}^{\mathrm{Comp}}\left(C_{L}^{\mathrm{Pb}}-C_{0}^{\mathrm{Pb}}\right)\right. \\
\left.+\beta_{\mathrm{Sn}}^{\text {Comp }}\left(C_{L}^{\mathrm{Sn}}-C_{0}^{\mathrm{Sn}}\right)\right] .
\end{gathered}
$$

The model can predict the shrinkage at the beginning of the solidification process.

Figure 10 shows modeling results for the volume change of $\mathrm{Cu}-5 \mathrm{Sn}-5 \mathrm{Zn}-5 \mathrm{~Pb}$ alloy as a function of temperature. In order to calculate the $\beta$ value of the $\mathrm{Cu}-5 \mathrm{~Pb}-5 \mathrm{Sn}-5 \mathrm{Zn}$ alloy, a term taking into account the zinc $\beta_{Z n}^{\text {Comp }}\left(C_{L}^{Z n}-C_{0}^{Z n}\right)$ was added to $(21)$.

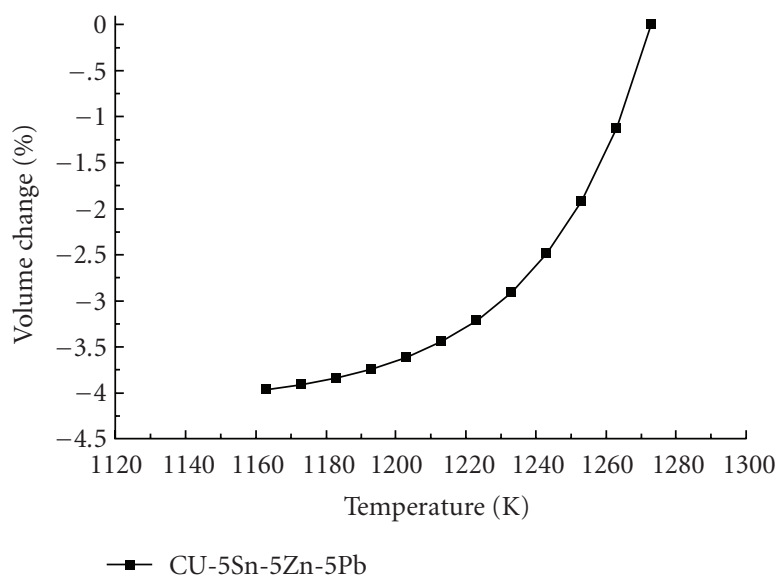

FIGURE 10: Modeling results of the solidification shrinkage in $\mathrm{Cu}-$ $5 \mathrm{Sn}-5 \mathrm{Zn}-5 \mathrm{~Pb}$ alloy.

\section{Discussion}

An evaluation of the microstructure of the $\mathrm{Cu}-5 \mathrm{~Pb}$ alloy shows that the fraction of solid is larger than the value calculated using the lever rule. This means that the solidification process occurred faster than the equilibrium prediction. The same behavior is observed in the $\mathrm{Cu}-5 \mathrm{Sn}-5 \mathrm{~Pb}$ alloy, in which the experimental values were compared with the calculated values using Scheil's equation.

The theoretical calculation of shrinkage presented in Figures 8 and 9, together with the measured values, shows that the measured shrinkage during solidification is smaller than the calculated one. As is mentioned above, the solid fraction measured by the quench experiment presented in Figure 2 shows that the volume fraction of the solid during the solidification process is larger than the obtained via equilibrium calculation. This deviation should increase the shrinkage because the solid has a larger density than the liquid. The explanation can be that the solid phase gets a larger volume than the equilibrium one during the solidification process due to the formation of lattice defects. This is also supported by the observation that the thermal contraction is larger than the equilibrium one at temperatures below the monotectic temperature. At these temperatures, it can be expected that the lattice defects condense and give a larger shrinkage. The condensation will contribute partly to shrinkage and partly to the formation of small pores.

A microprobe analysis of the $\mathrm{Cu}-5 \mathrm{Sn}-5 \mathrm{~Pb}$ alloy shows that the tin segregates during solidification. The segregation behavior is the same as in the $\mathrm{Cu}$-Sn system, but the partition coefficient value for the ternary alloy is less than the binary alloy, which means that the tin content in the primary solid is lower than the theoretical prediction obtained using the binary phase diagram. The segregation of tin increases when zinc is added to the ternary alloy. On the other hand, zinc has a different segregation profile during which the solid phase has a higher zinc content instead of the liquid in comparison with the $\mathrm{Cu}-\mathrm{Zn}$ system. Thus, the partition coefficient of zinc is more than one in the $\mathrm{Cu}-5 \mathrm{Sn}-5 \mathrm{Zn}-5 \mathrm{~Pb}$ alloy. Theoretical 
calculations show that (2) and (3) can be used to evaluate segregation of the alloying elements in the $\mathrm{Cu}-\mathrm{Sn}-\mathrm{Pb}$ system.

The experimental and the theoretical analyses show that the shrinkage decreases with an increasing lead and tin content. Equation (9) is used to define $\beta$ for the alloys. This can help us find alloys with no shrinkage. In the copper-lead system, we must define a $\beta^{\text {Total }}$ that included the premonotectic shrinkage, the volume change during the monotectic reaction, and the volume change due to the solidification of the remaining liquid after the monotectic reaction. Therefore, $\beta^{\text {Total }}$ value can be written as

$$
\beta^{\text {Total }}=f_{\text {Mono }}^{L / \text { pre }} \beta^{\text {pre-Mono }}+f_{\text {Mono }} \beta^{\text {Mono }}+f_{\text {Mono }}^{L / \text { pro }} \beta^{\text {pro-Mono }},
$$

where $f_{\text {Mono }}^{L / p r e}$ is the amount of liquid at the start of monotectic. $f_{\text {Mono }}$ is the amount of monotectic liquid. $f_{\text {Mono }}^{L / \text { pro }}$ is the amount of promonotectic liquid. $\beta^{p r e-M o n o}$ is given by (12). $\beta^{\mathrm{Mono}}$ is found by dividing relation (14) by the specific volume of the monotectic liquid. $\beta^{\text {pro-Mono }}$ is given by (10) and (11) when they are applied to a liquid with a $\mathrm{Cu}-$ rich composition as a starting point.

In the $\mathrm{Cu}-\mathrm{Pb}$ system, if an alloy with monotectic composition solidifies with no primary phase, then the first part of (22) disappears. The second part is also zero, as was already mentioned. Therefore, the remaining part is a volume change due to the precipitation of a $\mathrm{Cu}$-rich solid from a $\mathrm{Pb}$-rich liquid. According to the literature data $[6$, $11]$, the specific volume of the solid below the monotectic temperature $\left(V_{S}^{\mathrm{Cu}-\mathrm{Mono}}\right)$ is $0.1183 \mathrm{~cm}^{3} \mathrm{~g}^{-1}$, and the specific volume of the liquid $\left(V_{L-\text { Mono }}^{\mathrm{Cu}-\mathrm{Pb}}\right)$ is $0.0996 \mathrm{~cm}^{3} \mathrm{~g}^{-1}$. Therefore, the solidification process will continue to precipitate a solid with a higher volume than the liquid, which means that the volume change is an expansion due to a change from a higher-density liquid to a lower-density solid state.

The volume change of the $\mathrm{Cu}-5 \mathrm{Sn}-5 \mathrm{~Pb}$ alloy appeared as an expansion when the temperature decreased to the monotectic temperature. It seems that, below the monotectic temperature, the volume change is positive due to the precipitation of a lower-density solid from a higher-density liquid. The expansion can compensate primary solidification shrinkage in the alloy (which is assumed a reason for the pressure tightness of the alloy [5]).

\section{Conclusion}

A differential thermal analysis shows that the liquidus temperature decreases when zinc is added to a $\mathrm{Cu}-\mathrm{Sn}-\mathrm{Pb}$ alloy, but the monotectic temperature increases. Furthermore, the fraction of solid during solidification is larger than the equilibrium one in the $\mathrm{Cu}-5 \mathrm{~Pb}$ and the $\mathrm{Cu}-5 \mathrm{Sn}-5 \mathrm{~Pb}$ alloys.

Microsegregation measurements in the quenched samples show that the partition coefficient of Sn in the ternary alloy is less than the equilibrium value, which is calculated from the $\mathrm{Cu}-\mathrm{Sn}$ binary system. The partition coefficient of $\mathrm{Sn}$ decreases even more when $\mathrm{Zn}$ is added to the alloy. Zinc segregates negatively in the $\mathrm{Cu}-5 \mathrm{Sn}-5 \mathrm{Zn}-5 \mathrm{~Pb}$ alloy. The partition coefficient of zinc is equal to 1.89 .
Thermal contraction measurements show that the solidification shrinkage decreases when the lead content increases in the $\mathrm{Cu}-\mathrm{Pb}$ alloys. In addition, the solidification shrinkage decreases when the cooling rate is increased. On the other hand, below the monotectic temperature, the thermal contraction of the alloy increases with the cooling rate.

The theoretical analysis of shrinkage shows that the measured shrinkage during solidification is smaller than the calculated one. The volume change measurements suggest that the difference between the calculated and the measured values is a result of nonequilibrium solidification.

\section{Acknowledgments}

Financial support by Sabzevar Tarbiat Moallem University and the Ministry of Science, Research and Technology of Iran is greatly acknowledged.

\section{References}

[1] G. V. Raynor, The Cu-Sn Phase Diagram, Annotated. Equilibrium Diagram Series, The Institute of Metals, London, UK, 1944.

[2] D. Hansen and W. T. Pell-Walpole, Chill-Cast Tin Bronzes, London, UK, 1951.

[3] V. S. Briesemeister, "Die Mischungslücke in den Systemen Blei-Kupfer und Blei-Kupfer-Zinn," Zeitschrift für Metallkunde, vol. 23, pp. 225-230, 1931.

[4] A. Couture and J. O. Edwards, Cast Metals Research Journal, vol. 3, pp. 57-79, 1967.

[5] L. Ekbom, Foundry Trade Journal, vol. 109, pp. 355-361, 1960.

[6] T. Malmberg, "Determination of the specific volume of liquid copper-lead alloys," Institute of Metals Journal, vol. 89, pp. 137$139,1960$.

[7] B. K. Dhindaw, T. Antonsson, J. Tinoco, and H. Fredriksson, "Solidification-characterization of the peritectic reaction in medium-alloy steel through microsegregation and heat-oftransformation studies," Metallurgical and Materials Transactions A, vol. 35, no. 9, pp. 2869-2879, 2004.

[8] K. Zeng and J. K. Kivilahti, "Use of multicomponent phase diagrams for predicting phase evolution in solder/conductor systems," Journal of Electronic Materials, vol. 30, no. 1, pp. 3544, 2001.

[9] D. T. Hawkings and R. Hultgren, Eds., Metals Handbook, vol. 8, ASM, Metals Park, Ohio, USA, 1973.

[10] H. Fredriksson and U. Åkerlind, Materials Processing during Casting, John Wiley \& Sons, London, UK, 2006.

[11] J. Miettinen, "Thermodynamic-kinetic model for the simulation of solidification in binary copper alloys and calculation of thermophysical properties," Computational Materials Science, vol. 36, no. 4, pp. 367-380, 2006.

[12] C. J. Smithells, Metals Reference Book, ButterworthHeinemann, London, UK, 5th edition, 1976. 

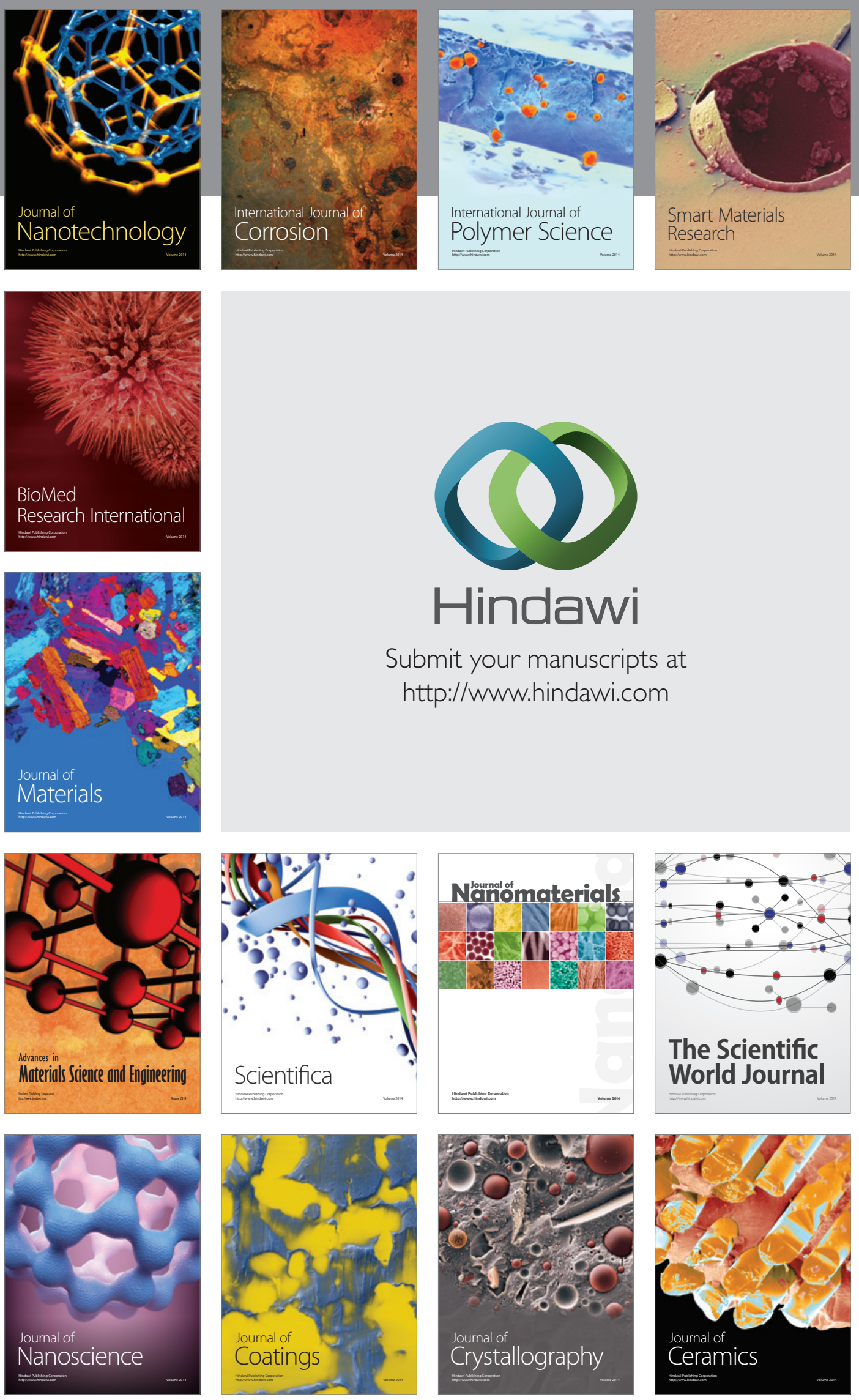

The Scientific World Journal

Submit your manuscripts at

http://www.hindawi.com

\section{World Journal}

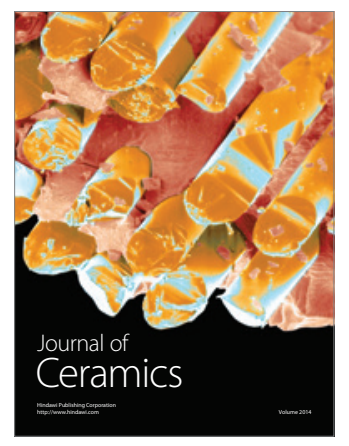

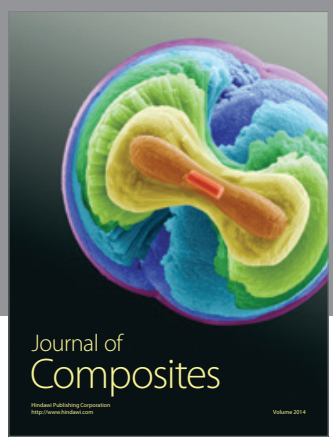
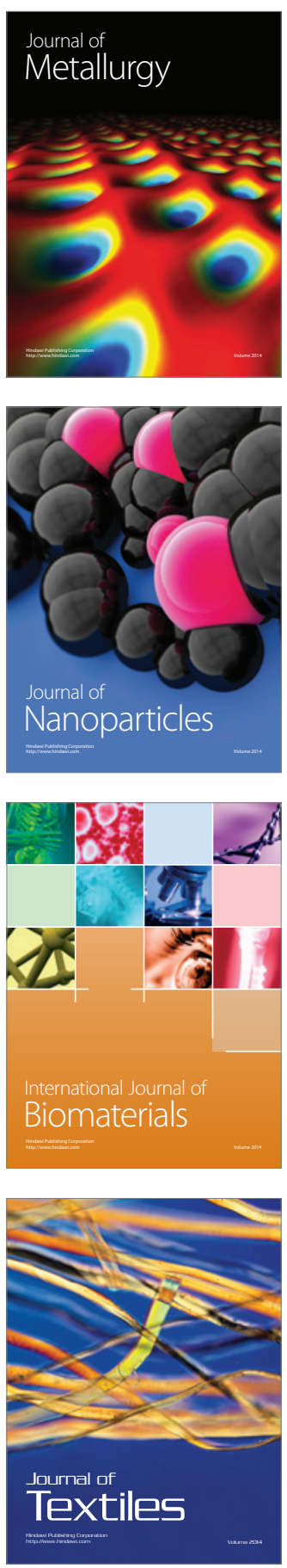